\title{
Penyajian Informasi Lokasi Bencana Menggunakan Sistem Informasi Geografis Berbasis Web Service
}

\author{
A Mulyanto 1), R Takdir 2), DO Anwar ${ }^{3)}$ \\ 1),2),3) Jurusan Teknik Informatika, Fakultas Teknik, Universitas Negeri Gorontalo \\ email : arip.mulyanto@ung.ac.id
}

\begin{abstract}
Abstrak
Badan Penanggulangan Bencana Daerah (BPBD) Kabupaten Gorontalo menangani bencana dengan cara memasang rambu lalu lintas bencana sebagai informasi lokasi bencana kepada masyarakat. Akan tetapi informasi yang disampaikan belum lengkap dan meluas kepada masyarakat yang berada di luar Kabupaten Gorontalo. Tujuan dari penelitian ini adalah meningkatkan penyajian informasi lokasi bencana alam di Kabupaten Gorontalo menggunakan sistem informasi geografis. Penelitian ini menggunakan metode pengembangan sistem yaitu metode Prototype. Hasil penelitian menunjukkan bahwa Sistem Informasi Geografis Lokasi Bencana Alam dapat meningkatkan penyajian informasi lokasi bencana alam di Kabupaten Gorontalo. Sistem ini dapat membantu pihak BPBD Kabupaten Gorontalo dalam menyampaikan informasi bencana secara lengkap berupa informasi lokasi kejadian bencana, jenis bencana, jumlah penduduk, jumlah korban bencana, dan detail korban bencana kepada masyarakat. Sistem ini menggunakan teknologi sms gateway sebagai pintu gerbang untuk menerima sms laporan masyarakat saat terjadi bencana dan menggunakan teknologi web service sebagai pertukaran data dengan sistem informasi penyaluran bantuan logistik.
\end{abstract}

Kata Kunci: Sistem Informasi Geografis, Web Service, SMS Gateway

\section{Abstract}

Regional Disaster Management Agency (BPBD) in Gorontalo Regency handles disasters by installing disaster traffic signs as information on the location of disasters to the public. However, the information conveyed was not complete not widespread enough to people outside of Gorontalo District. The purpose of this study is to improve the presentation of information on the location of natural disasters in Gorontalo Regency using a geographic information system. This study uses a system development method, the Prototype method. The results showed that the Geographic Information System for Natural Disaster Locations can improve the presentation of information on the location of natural disasters in Gorontalo District. This system can help the $B P B D$ in Gorontalo Regency in delivering complete disaster information in the form of information on the location of a disaster event, type of disaster, population, number of victims, and details of disaster victims to the community. This system uses SMS gateway technology as a means to receive SMS reports from the public during a disaster and uses web service technology as a way to exchange data with logistical assistance distribution information systems.

Keywords: Geographic Information Systems, Web service, SMS gateway

Diterima Mei 2018

Disetujui April 2018

Dipublikasi Juni 2018

C2018 A Mulyanto, R Takdir, DO Anwar Under the license CC BY-SA 4.0

\section{Pendahuluan}

Informasi lokasi bencana alam diperlukan oleh berbagai pihak untuk menyalurkan bantuan logistik bagi korban bencana. Salah satu upaya Badan Penanggulangan Bencana Daerah (BPBD) Kabupaten Gorontalo dalam memberikan 
informasi lokasi bencana alam di daerah Kabupaten Gorontalo, adalah dengan cara memasang rambu lalu lintas bencana sebagai informasi untuk masyarakat yang melintasi daerah bencana. Namun informasi tersebut hanya bisa diakses atau diketahui oleh BPBD Kabupaten Gorontalo dan masyarakat yang berada di daerah bencana alam. Informasi lokasi bencana belum disajikan secara meluas kepada masyarakat yang berada di luar Kabupaten Gorontalo. Akibatnya, bantuan logistik terdistribusi tidak merata. Ada daerah yang berlimpah bantuan dan ada daerah yang tidak mendapatkan bantuan.

Untuk itu, diperlukan sistem yang dapat menyajikan informasi tentang lokasi bencana yang membutuhkan penyaluran bantuan logistik kepada masyarakat. Salah satu sistem yang dapat menjadi alternatif adalah Sistem Informasi Geografis (SIG). Menurut Budianto (2010), SIG adalah sistem komputer yang memiliki kemampuan untuk mengambil, menyimpan, menganalisa, dan menampilkan informasi dengan referensi geografis. SIG menampilkan peta suatu wilayah yang dilengkapi dengan berbagai informasi yang diperlukan. Salah satu metode untuk memperoleh peta suatu wilayah adalah dengan menggunakan Google Maps API. Menurut Tulach (2008) Google Maps API adalah method atau fungsi serta signature sederhana yang memiliki banyak set class, dengan menggunakan Google Maps API dapat menghemat waktu dan biaya untuk membangun aplikasi SIG berbasis web, sehingga kita dapat fokus hanya pada data-data yang akan ditampilkan.

Untuk mempermudah pengintegrasian data dengan sistem terkait, aplikasi SIG ini menggunakan teknologi web service. Menurut Pratama (2016), Web service merupakan sebuah perangkat lunak komputer (Software) dalam bentuk sebuah fungsi pada sistem operasi, yang dirancang untuk mendukung interoperabilitas dan interaksi antar komputer di dalam jaringan komputer, dengan memanfaatkan tatap muka WSDL (Web Service Definition Language). Selain itu, untuk mempermudah distribusi informasi, aplikasi SIG ini menggunakan short message service (SMS) yang merupakan suatu teknologi nirkabel yang memungkinkan seseorang untuk mengirim dan menerima pesan secara cepat melalui perangkat mobile (Tarigan, 2012).

Penelitian ini merupakan pengembangan dari penelitian Latifah (2015) yang membahas tentang Sistem Informasi Geografis Pemetaan Daerah Rawan Bencana Alam di Kabupaten Kebumen Berbasis Web. Penelitian tersebut menghasilkan sebuah sistem informasi geografi daerah rawan bencana alam berbasis website yang dapat menampilkan informasi data history kejadian bencana alam tahun 2010-2014 berapa jumlah kejadian bencana alam yang disajikan dalam visualisasi peta digital dan mengelola data history kejadian bencana alam yang pernah terjadi sebelumnya di 
Kabupaten Kebumen. Pada penelitian ini, aplikasi GIS yang dibangun dapat menyajikan informasi bencana dan informasi daerah penyaluran bantuan logistik.

Penelitian ini bertujuan untuk meningkatkan penyajian informasi lokasi bencana alam di Kabupaten Gorontalo menggunakan sistem informasi geografis. Dengan sistem informasi ini dapat membantu pihak BPBD Kabupaten Gorontalo dalam memberikan informasi sebaran desa yang mengalami bencana alam di Kabupaten Gorontalo. Selain itu, sistem informasi ini dapat membantu pihak BPBD Kabupaten Gorontalo dalam memberikan informasi bencana secara lengkap yang meliputi jenis bencana, daerah yang mengalami bencana, dan jumlah penduduk, jumlah korban bencana, detail korban bencana dan item bantuan logistik yang dibutuhkan kepada masyarakat Provinsi Gorontalo.

\section{Metode}

Metode pengembangan sistem yang digunakan dalam penelitian ini yaitu dengan menggunakan metode Prototype (Prototyping). Metode Prototype sering digunakan oleh pengembang sistem karena metode ini secara keseluruhan mengacu kepada kepuasan user. Dengan metode Prototype ini pengembang dan pelanggan dapat saling berinteraksi selama proses pembuatan sistem. Berikut tahapan pada metode Prototype menurut Pressman (2012).

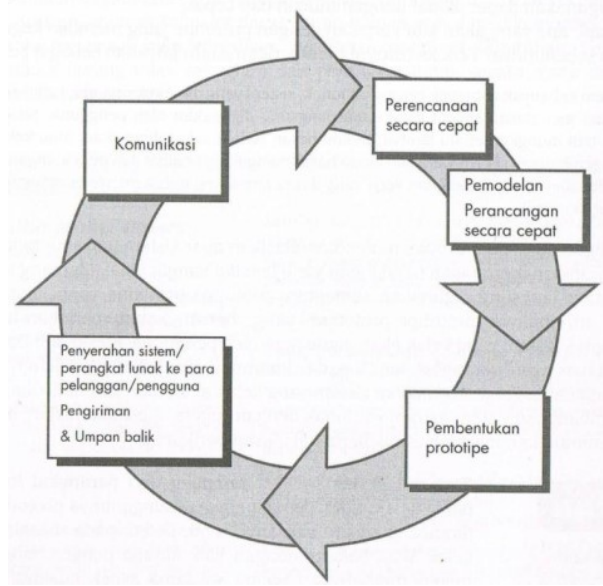

Gambar 1. Paradigma Pembuatan Prototype (Pressman, 2012)

1. Komunikasi dan Pengumpulan Kebutuhan

Pada tahap ini dilakukan komunikasi dengan Kepala dan staf Bidang Pencegahan dan Kesiapsiagaan dan pengumpulan data awal. Untuk mengidentifikasi spesifikasi kebutuhan pengguna digunakan metode analisis PIECES (Performance, Information, Economy, Control, Efficiency, Services). Dengan metode analisis PIECES dapat ditemukan permasalahan yang akan diteliti pada proses penyampaian informasi daerah yang mengalami bencana dan membutuhkan penyaluran bantuan logistik 
kepada masyarakat. Setelah melakukan komunikasi, dilakukan pengumpulan kebutuhan yang diperlukan dalam penelitian ini yakni data berupa data kecamatan, data desa beserta koordinat lokasi desa di Kabupaten Gorontalo, dan data kejadian. Selain itu, pengumpulan kebutuhan juga dilakukan dengan teknik wawancara dan studi pustaka.

\section{Perencanaan secara cepat}

Pada tahap ini dilakukan perencanaan secara cepat sebagai acuan untuk pemodelan dan perancangan secara cepat. Pada tahap ini digambarkan secara umum tentang sistem informasi geografis lokasi bencana alam.

3. Pemodelan dan perancangan secara cepat

Pada tahap ini dilakukan pemodelan data berupa data flow diagram dan pemodelan tabel basis data dari aplikasi yang dibuat. Data tersebut berupa data kecamatan, data desa beserta koordinat lokasi desa, data kejadian, data detail kejadian, dan data laporan masyarakat. Kemudian akan dilakukan perancangan secara cepat seperti rancangan antar muka pengguna (user interface) atau format tampilan.

\section{Pembentukan Prototype}

Pada tahap ini dibangun sebuah sistem dengan menggunakan bahasa pemograman PHP dan penyimpanan database menggunakan MySQL sesuai dengan pemodelan data dan rancangan cepat yang telah disepakati sebelumnya oleh pelanggan dan pengembang perangkat lunak.

5. Penyerahan prototype ke para pelanggan/pengguna, Pengiriman \& Umpan balik

Pada tahap ini dilakukan penyerahan prototype kepada pengguna yaitu pegawai BPBD Kabupaten Gorontalo bidang Pencegahan dan Kesiapsiagaan untuk di evaluasi apakah perancangan Prototype yang dibangun sudah sesuai dengan keinginan atau kebutuhan pengguna. Dalam tahap ini juga dilakukan pengujian pada aplikasi yang dibuat nanti. Tahap ini diperlukan untuk melihat tingkat keberhasilan sistem apakah layak digunakan. Pada penulisan ini proses pengujian sistem dilakukan dengan metode Black Box Testing.

\section{Hasil Dan Pembahasan}

\section{Hasil}

\section{Pembentukan Prototype}

Pada tahap ini dijelaskan bagaimana fungsi dari masing-masing halaman yang terdapat pada Aplikasi Sistem informasi geografis lokasi bencana alam yang telah dibuat. 
1. Halaman Form User

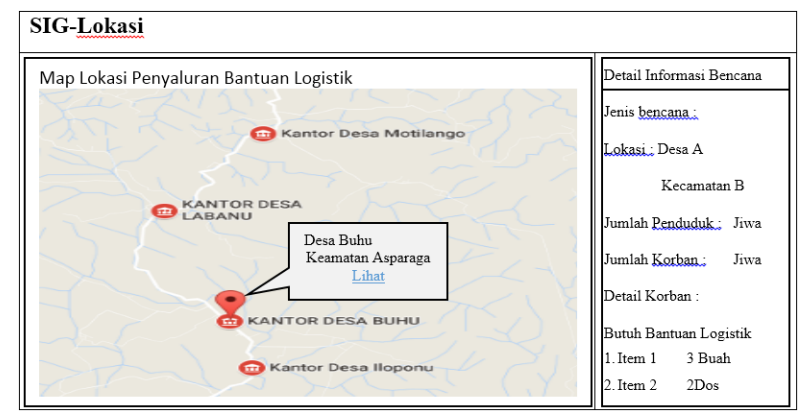

Gambar 6. Form User (Pengguna)

\section{Halaman Sebaran Desa}

Halaman ini merupakan halaman untuk menampilkan sebaran lokasi desa yang telah dinput koordinat lokasinya seperti yang terlihat pada gambar 7 .

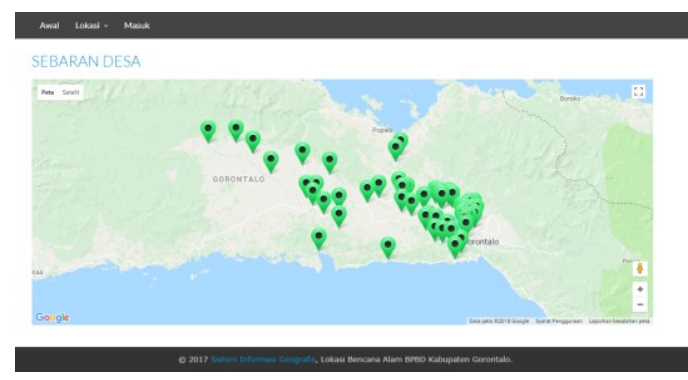

Gambar 7. Halaman Sebaran Desa

3. Halaman SMS Laporan Masyarakat

Halaman ini menampilkan sms dari laporan masyarakat terhadap kejadian bencana yang telah terjadi dengan format sms yakni jenis bencana\#nama desa\#jumlah penduduk. Berikut gambar 8 yang merupakan sms laporan masyarakat sesuai dengan format sms.

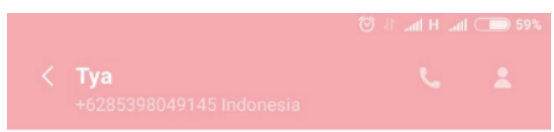

\section{Banjir\#llupoyo $\# 3000$}

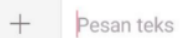

Gambar 8. SMS Laporan Masyarakat

4. Halaman Pengguna 
Halaman ini menampilkan informasi bencana dalam bentuk maps kepada masyarakat dimana lokasi yang telah terjadi bencana akan menampilkan titik koordinatnya. Berikut gambar 9 yang merupakan halaman dengan menampilkan informasi lokasi bencana di Kabupaten Gorontalo.

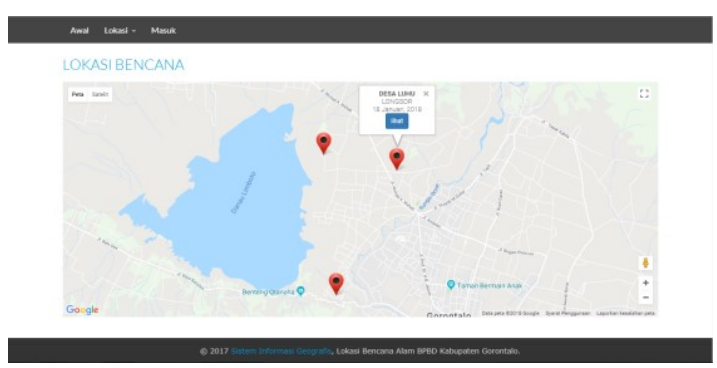

Gambar 9. Halaman Lokasi Bencana

Saat informasi lokasi bencana tersebut tampil dan lokasinya di klik, akan tampil nama desa, jenis bencana dan tanggal kejadian serta ikon tombol lihat. Ikon ini berfungsi untuk menampilkan detail informasi bencana pada lokasi kejadian. Berikut gambar 10 yang merupakan halaman dengan menampilkan detail bencana dari lokasi kejadian.

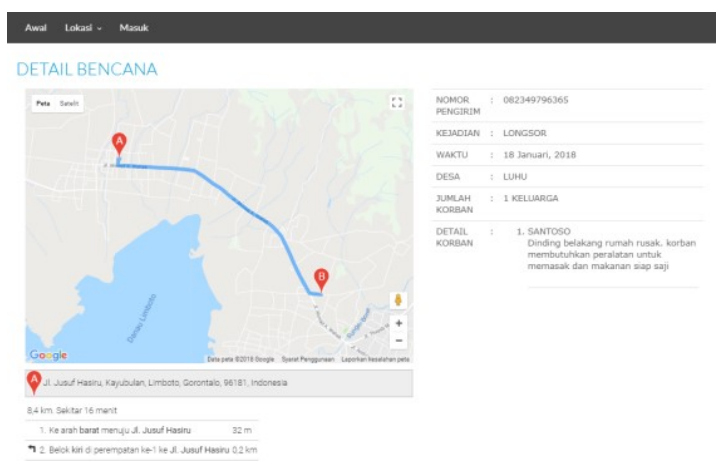

\section{Gambar 10. Halaman Detail Bencana}

\section{Pembahasan}

Dalam menangani bencana, BPBD Kabupaten Gorontalo memberikan informasi tentang bencana kepada masyarakat sebagai informasi kehati-hatian melintas dengan memasang rambu lalu lintas. Akan tetapi informasi yang disampaikan tidak secara meluas kepada masyarakat yang berada diluar Kabupaten Gorontalo. Dengan adanya sistem informasi geografis lokasi bencana alam dapat menjadi solusi dari permasalahan.

Sistem informasi geografis lokasi bencana alam dapat menyajikan informasi bencana ke masyarakat Provinsi Gorontalo seperti yang terlihat pada gambar 9 dan gambar 10. Informasi bencana yang disajikan berupa informasi lokasi kejadian, jenis bencana, jumlah penduduk, jumlah korban bencana dan detail korban bencana. Selain 
itu, sistem ini juga menyajikan informasi lokasi desa yang ada di Kabupaten Gorontalo seperti yang terlihat pada gambar 7 .

Sistem ini dapat menerima sms laporan masyarakat saat terjadi bencana dengan menggunakan teknologi sms gateway seperti yang terlihat pada gambar 8. Sms laporan masyarakat yang diterima oleh sistem ini, akan diteruskan ke petugas dari Bidang Kedaruratan dan Logistik. Saat petugas telah melakukan survei, data hasil survei akan masuk ke sistem ini melalui sistem informasi penyaluran bantuan logistik sehingga informasi yang diterima masyarakat lengkap.

Selain itu, sistem ini menggunakan teknologi web service untuk pertukaran data dengan sistem informasi penyaluran bantuan logistik. Pada sistem ini terdapat pembatasan akses bagi pengguna, dimana bidang Pencegahan dan Kesiapsiagaan yang dapat mengolah data dalam sistem sedangkan masyarakat hanya dapat melihat hasil olahan data dalam bentuk informasi yang telah disajikan. Pada tabel 3 menjelaskan tentang fungsi web service dari kolaborasi dua sistem.

Tabel 3. Fungsi Web Service

\begin{tabular}{|c|c|c|c|c|c|}
\hline Data & IP & Method & $\begin{array}{c}\text { Sistem } \\
\text { yang } \\
\text { mengirim }\end{array}$ & $\begin{array}{c}\text { Data yang } \\
\text { dikirim }\end{array}$ & $\begin{array}{c}\text { Data yang } \\
\text { diterima }\end{array}$ \\
\hline User & $\begin{array}{l}\frac{\text { http://localhost/sipa }}{\text { blo/index.php/api/c }} \\
\text { ek user/Stoken }\end{array}$ & GET & $\begin{array}{l}\text { SI } \\
\text { PABLO }\end{array}$ & $\begin{array}{l}\text { Token dan } \\
\text { Nama } \\
\text { Service } \\
\text { (cek_user) }\end{array}$ & $\begin{array}{l}\text { Username } \\
\text { dan } \\
\text { Password }\end{array}$ \\
\hline $\begin{array}{l}\text { Kecamat } \\
\text { an }\end{array}$ & $\begin{array}{l}\text { http://localhost } / \text { sipa } \\
\text { blo/index.php/api/g } \\
\text { et camat } / \text { Stoken }\end{array}$ & GET & $\begin{array}{l}\text { SI } \\
\text { PABLO }\end{array}$ & $\begin{array}{l}\text { Token dan } \\
\text { Nama } \\
\text { Service } \\
\text { (get_cama } \\
\text { t) }\end{array}$ & \begin{tabular}{|l|} 
Daftar \\
Kecamatan
\end{tabular} \\
\hline Desa & $\begin{array}{l}\text { http://localhost } / \text { sipa } \\
\text { blo/index.php/api/g } \\
\text { et desa/ } / \text { token }\end{array}$ & GET & $\begin{array}{l}\text { SI } \\
\text { PABLO }\end{array}$ & $\begin{array}{l}\text { Token dan } \\
\text { Nama } \\
\text { Service } \\
\text { (get_desa) }\end{array}$ & Daftar desa \\
\hline Korban & $\begin{array}{l}\frac{\mathrm{http}: / / \text { localhost/sipa }}{\mathrm{blo} / \text { index.php/api/a }} \\
\text { mbil data korban/\$ } \\
\text { token }\end{array}$ & GET & $\begin{array}{l}\text { SI } \\
\text { PABLO }\end{array}$ & $\begin{array}{l}\text { Token dan } \\
\text { nama } \\
\text { service } \\
\text { (ambil_dat } \\
\text { a_korban) }\end{array}$ & $\begin{array}{l}\text { Data } \\
\text { Korban }\end{array}$ \\
\hline $\begin{array}{l}\text { Laporan } \\
\text { masyara } \\
\text { kat }\end{array}$ & $\begin{array}{l}\frac{\mathrm{http}: / \text { localhost/sipa }}{\mathrm{blo} / \text { index.php/api/si }} \\
\text { mpan laporan/\$tok } \\
\text { en }\end{array}$ & GET & $\begin{array}{l}\text { SI } \\
\text { PABLO }\end{array}$ & \begin{tabular}{|l|} 
Pesan \\
berhasil \\
diterima
\end{tabular} & $\begin{array}{l}\text { Laporan } \\
\text { masyarakat } \\
\text { dan Token }\end{array}$ \\
\hline
\end{tabular}

\section{Kesimpulan}

Berdasarkan hasil penelitian, maka dapat ditarik kesimpulan bahwa sistem informasi geografis lokasi bencana alam dapat meningkatkan penyajian informasi lokasi bencana alam di Kabupaten Gorontalo. Sistem ini dapat membantu pihak BPBD Kabupaten Gorontalo dalam menyampaikan informasi sebaran desa yang mengalami bencana alam di Kabupaten Gorontalo. Serta dapat menyampaikan informasi bencana secara lengkap berupa informasi jenis bencana, daerah yang mengalami bencana, dan jumlah penduduk, jumlah korban bencana, detail korban bencana dan item bantuan logistik yang dibutuhkan kepada masyarakat Provinsi 
Gorontalo. Selain itu, sistem ini dapat menerima sms laporan masyarakat saat terjadi bencana dengan menggunakan teknologi sms gateway. Dan sistem ini menggunakan teknologi web service untuk pertukaran data dengan sistem informasi penyaluran bantuan logistik.

\section{Daftar Pustaka}

Budianto, Eko. 2010. Sistem Informasi Geografis dengan Arc View Gis. Yogyakarta : Andi Offset

Latifah, Nur Azizah. 2015. Sistem Informasi Geografis Pemetaan Daerah Rawan Bencana Alam Di Kabupaten Kebumen Berbasis Web. Skripsi Program Studi Teknik Informatika. Yogyakarta : Universitas Islam Negeri Sunan Kalijaga

Pratama, I Putu Agus Putu. 2016. Integrasi dan Migrasi Sistem. Bandung : Informatika

Pressman, Roger S. 2012. Rekayasa Perangkat Lunak. Yogyakarta : Andi

Tarigan, Daud Edison. 2012. Membangun SMS Gateway Berbasis Web Dengan Codeigniter. Yogyakarta : Lokomedia.

Tulach. 2008 Google Map API. (Online). (http://library.binus.ac.id/eColls/eThesisdoc/Bab2HTML/2012100267ifbab2/pag e31.html, diakses 31 Mei 2017) 